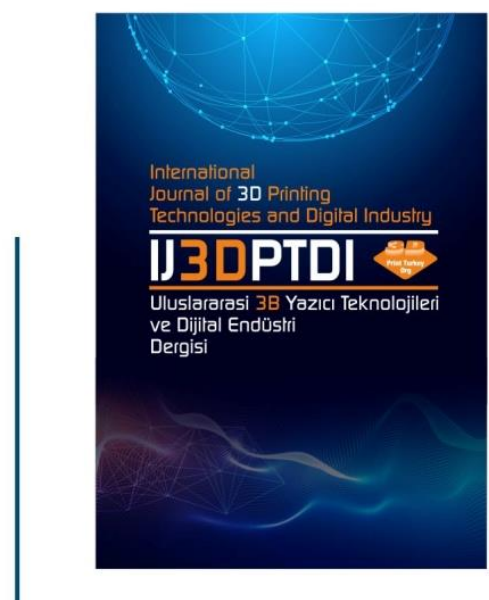

ULUSLARARASI 3B YAZICI TEKNOLOJILERI

VE DIJITAL ENDÜSTRI DERGISI

INTERNATIONAL JOURNAL OF 30 PRINTING TECHNOLOGIES AND DIGITAL INDUSTRY

IS5N:2602-3350 [Online]

URL: https://dergipark.org.tr/ij3dptdi

\title{
DEVELOPMENT OF MULTI-MATERIAL COMPONENTS VIA ROBOTIC WIRE ARC ADDITIVE MANUFACTURING
}

Yazarlar (Authors): Uğur Gürol ${ }^{\mathbb{D} *}$, Batuhan Turgut ${ }^{\mathbb{D}}$, Nurten Güleçyüz ${ }^{\mathbb{D}}$, Savaş Dilibal (iD), Mustafa Koçak iD

Bu makaleye şu şekilde atıfta bulunabilirsiniz (To cite to this article): Gürol U., Turgut B., Güleçyüz N., Dilibal S., and Koçak M. "Development Of Multi-Material Components Via Robotic Wire Arc Additive Manufacturing", Int. J. of 3D Printing Tech. Dig. Ind., 5(3): 721-729, (2021). 


\title{
DEVELOPMENT OF MULTI-MATERIAL COMPONENTS VIA ROBOTIC WIRE ARC ADDITIVE MANUFACTURING
}

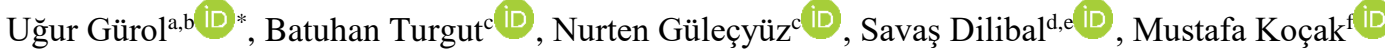 \\ ȧstanbul Gedik University, Engineering Faculty, Metallurgical \& Materials Engineering Department, TURKEY \\ bístanbul Gedik University, Welding Technology Research and Application Center, TURKEY \\ ${ }^{\mathrm{c}}$ Gedik Welding Inc., Research and Development Center, TURKEY \\ dİstanbul Gedik University, Engineering Faculty, Mechatronics Engineering Department, TURKEY \\ eIstanbul Gedik University, Robot Technology Research and Application Center, TURKEY \\ fístanbul Gedik University, Engineering Faculty, Mechanical Engineering Department, TURKEY \\ *Corresponding Author: ugur.gurol@yahoo.com
}

(Received: 06.12.2021; Revised: 24.12.2021; Accepted: 28.12.2021)

\begin{abstract}
Additive manufacturing technologies are applied in different industrial fields. It is possible to produce 3D parts in complex form at a lower cost with faster production capability using additive manufacturing compared to traditional subtractive manufacturing. Robotic welding-based wire arc additive manufacturing (WAAM) is a novel additive manufacturing technology which offers various solutions. Many products can be produced through the additive manufacturing in the fields of defense, aerospace, and automotive industries. In this study, multi-material metallic parts were produced by depositing ferritic ER 70 S-6 and stainless steel ER316L welding wires using robotic WAAM technology. Detailed microstructural analysis and hardness tests were conducted on the manufactured samples including interfaces between two different materials. Characterization of Fe-austenite weld interfaces has shown the presence of hard phases due to migration of hardening elements. The microhardness examination revealed that the highest hardness values are recorded at the bimetallic interface due to $\mathrm{Fe}$ and $\mathrm{C}$ migration through the interface layer.
\end{abstract}

Keywords: Additive manufacturing, WAAM, Robotic arc welding, Multi-material, microstructure characterization, Vickers hardness

\section{INTRODUCTION}

Additive manufacturing technologies, which are main components of the Industry 4.0 concept, are attracting high interest in many industrial fields, such as defense [1], aerospace [2] and automotive industries [3]. Among the direct energy deposition (DED)-based additive manufacturing methods, WireArc Additive Manufacturing (WAAM) provides high layer deposition rate with reduced material wastage and shortened production time compared to the powder-based processes. WAAM technology is more suitable for manufacturing larger components compared to other additive manufacturing methods. [4]. Electric arc welding is the energy source to melt the welding wire (either solid or metal cored wire) in WAAM process. The shielding gas environment enables to deposit of the molten metal layers protected from air. Additionally, commercially available welding consumables can easily be used as a consumable in WAAM technologies [5].

In recent years, many researchers conducted studies in WAAM technology using single welding wires such as Ti-alloys (Ti6Al4V), Al-alloys (Al-6Mg), steels (316L, low alloy steels), Inconel 718 nickelbased super alloys, AZ31 Mg- alloys, Cu-based alloys [6-8]. Industrial robots, electric arc melting, metal deposition and cooling cycle path are the vital elements of the WAAM process. The solidification speed of the molten metal decreases with increased heat input while increased wire feed rate lowers the stability of the molten pool [9-10]. 
The temperature gradient direction, welding current mode, cooling time and interlay temperature affect the macroscopic characteristic and microstructure of the deposited layers [11]. The heat input, speed, wire feed rate, solidification rate, deposition current, the inter-pass temperature and the torch travel speed are used as important parameters for WAAM process [12]. The heat input, inter-pass temperature, cooling rate \& time should carefully be monitored to avoid any solidification cracking. It is known that these process parameters control the evolved microstructure and the mechanical properties of the deposited layers. The layers should be positioned carefully to ensure geometrical accuracy for the planned component and with the desired microstructure. The welding current level, torch linear movement rate, wire feed rate, torch height, shielding gas type, gas flow rate, tool path orientation and oscillation frequency are the main process parameters of the WAAM. These parameters are carefully controlled during this study since multi-material process was the topic of interest.

In the literature, there is a limited number of studies regarding the multi-material-based WAAM process [13-15]. In this study, multi-material parts were produced by depositing ferritic ER 70 S-6 and stainless steel ER316L welding wires using robotic WAAM technology to investigate the formation of the interfacial characteristics between dissimilar materials. This communication covers only microstructural analysis and hardness tests to clarify the microstructural features of the ferrite-austenite combination fabricated using WAAM process for multi-material parts.

\section{EXPERIMENTAL PROCEDURE}

The equipment of the WAAM process is established with the robot cell for robotic arc welding, as shown in Figure 1. The welding robot of OTC Daihen FD-V8L is used in the robot cell. GeKaMac Power MIG GPS WB P500L power source is integrated into the robot cell as a synergic welding machine. In the additive manufacturing process, a short arc with high arc stability is utilized with the low spatter control (LSC) process. Low spatter formation and high melting power are obtained with high quality stable welding process in the LSC process.

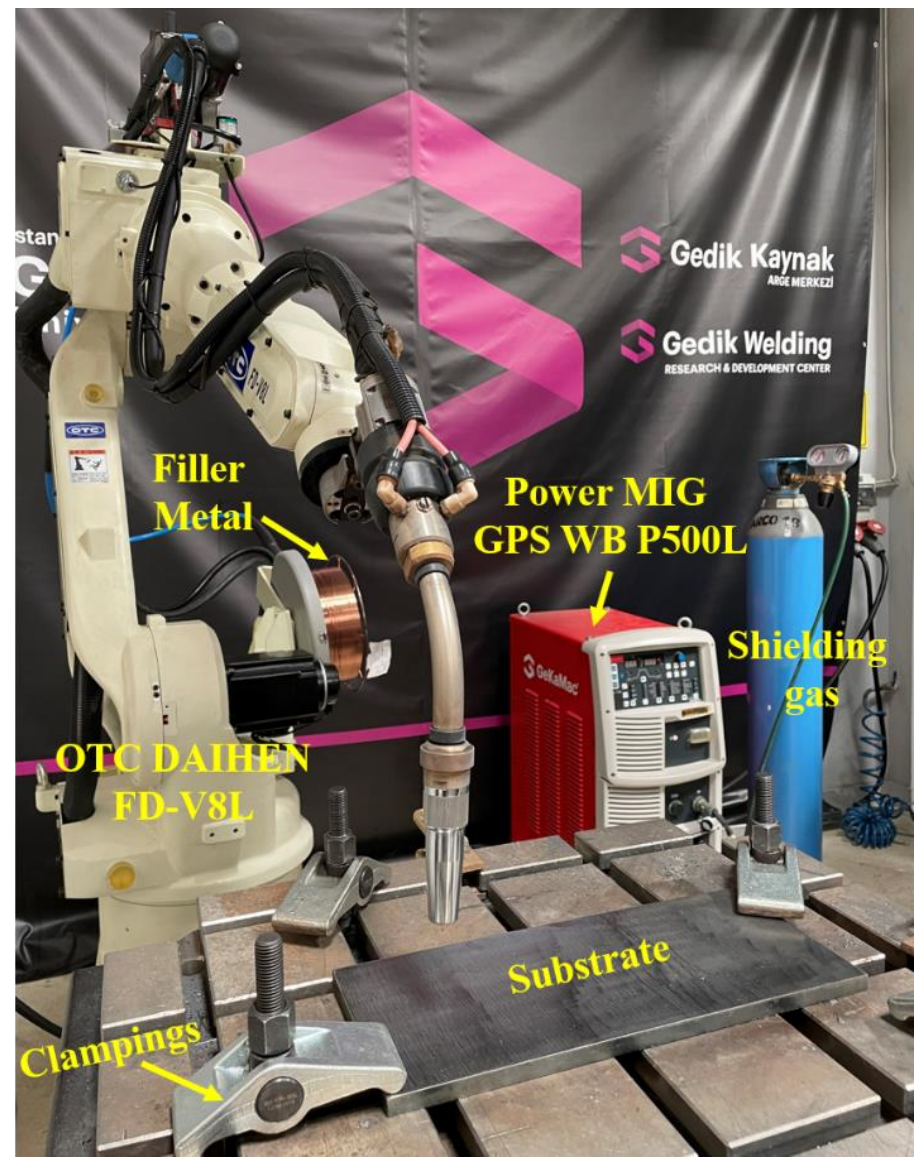

Figure 1. The robot cell for the robotic arc additive manufacturing process. 
The multi-material part is built using two different welding wires through WAAM technology. The schematic illustration of the layers of the multi-material square part is given in Figure 2.

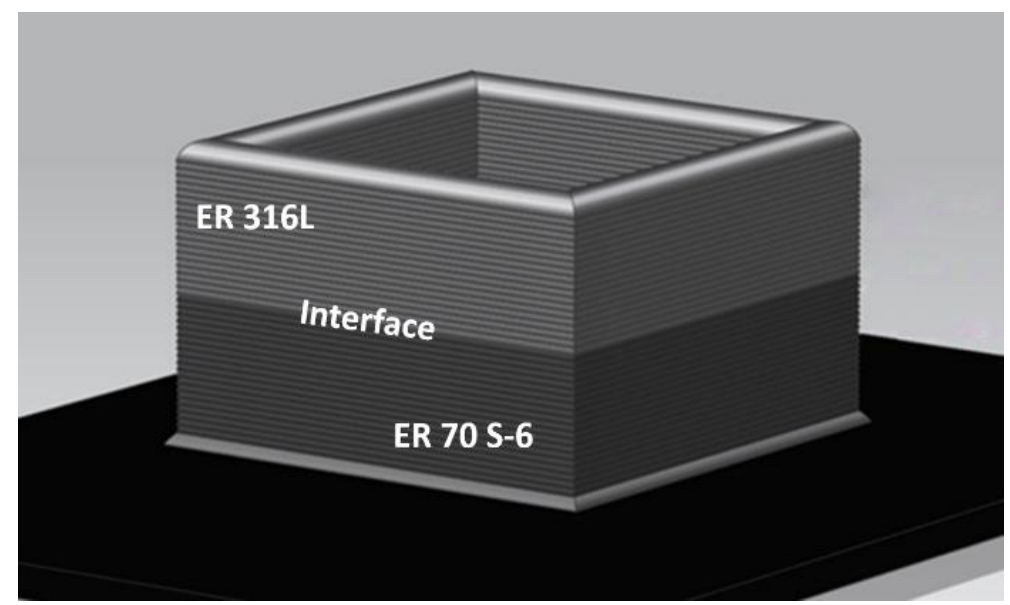

Figure 2. Schematic illustration of the deposited layers of the multi-material component.

The initial root-pass and inter-pass layers are produced with ferritic ER 70 S-6 coded low carbon steel massive welding wire of $1.2 \mathrm{~mm}$. After ten layers of welding passes, material-B layers are deposited on it to produce bi-metal component while the material-B was ER316L austenitic stainless steel welding wire. The chemical compositions of the ER 70 S- 6 and ER316L are given in Table 1. The shielding gas of $18 \% \mathrm{CO} 2$ and $2.5 \% \mathrm{CO} 2$ in argon are used during the deposition of ER 70 S-6 and ER316L, respectively.

Table 1. The chemical composition of the filler metals (in wt. \%)

\begin{tabular}{lccccccccc}
\hline \hline Material & $\mathbf{C}$ & $\mathbf{S i}$ & $\mathbf{M n}$ & $\mathbf{P}$ & $\mathbf{S}$ & $\mathbf{N i}$ & $\mathbf{C r}$ & $\mathbf{C u}$ & $\mathbf{M o}$ \\
\hline \hline ER 70 S-6 & 0.08 & 0.84 & 1.48 & 0.015 & 0.014 & 0.05 & 0.02 & 0.08 & 0.01 \\
ER 316 L & 0.02 & 0.61 & 1.63 & 0.022 & 0.005 & 10.46 & 16.37 & 0.10 & 1.99 \\
\hline \hline
\end{tabular}

It is known that the welding deposition parameters determine the thermal history and efficiency of the WAAM process. The applied welding voltage, electric current, wire diameter, welding speed and torch angle are given in Table 2.

Table 2. Welding parameters for wire arc additive manufacturing

\begin{tabular}{lccc}
\hline \hline Process parameters & Units & ER 70 S-6 & ER 316 L \\
\hline \hline Voltage & $\mathrm{V}$ & 14.6 & 15.3 \\
Current & $\mathrm{A}$ & 132 & 150 \\
Wire diameter & $\mathrm{mm}$ & 1.0 & 1.0 \\
Moving speed & $\mathrm{cm} / \mathrm{min}$ & 50 & 50 \\
Torching angle & degree & 90 & 90 \\
Interpass temperature & ${ }^{\circ} \mathrm{C}$ & 30 & 30 \\
Shielding gas & - & $82 \% \mathrm{Ar}+18 \% \mathrm{CO}_{2}$ & $97.5 \% \mathrm{Ar}+2.5 \% \mathrm{CO}_{2}$ \\
Gas flow rate & $\mathrm{L} / \mathrm{min}$ & 15 & 15 \\
\hline \hline
\end{tabular}

Four thin-walled rectangular component was additively manufactured using the above-mentioned parameters and conditions during the WAAM process. The final form of the WAAM processed component is shown in Figure 3 together with its cross-sectional profiles used for microstructural investigation and hardness tests. The surface of the polished specimen was first etched electrochemically with a potential of $12 \mathrm{~V}$ for $45 \mathrm{~s}$ using $25 \% \mathrm{NaOH}$ to obtain phase contrast in the ER 316L side and then etched for $5 \mathrm{~s}$ using the \% 3 Nital to unveil the microstructural features on the ER 70 S-6 side. Moreover, $\mathrm{X}$-ray radiographic test was conducted to detect any defects which may be present in the WAAM processed component. 

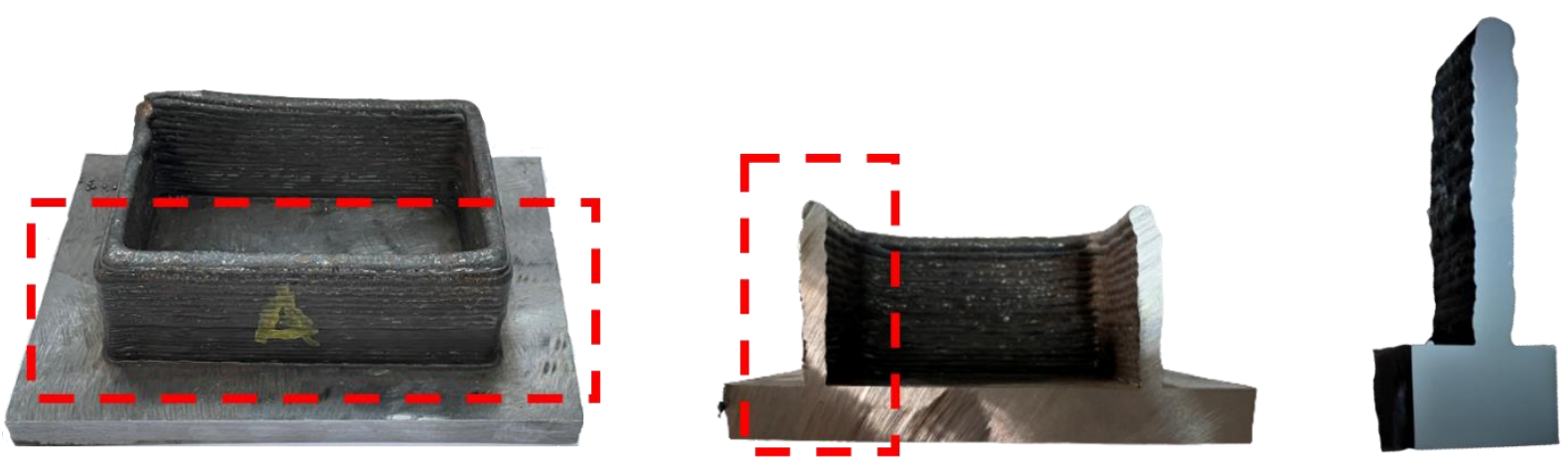

Figure 3. The final form of the WAAM processed as-built component and the specimen preparation process.

The microstructural characterization of additively manufactured layers is conducted using the Leica DMi8 optical microscope with the magnification of 200x. Microhardness measurements are performed through cross-section of polished specimens covering each ER 316L, transition zone, and ER 70 S-6 side with an interval of $500 \mu \mathrm{m}$ using image-controlled device with a brand of Struers DuraScan G5 under $500 \mathrm{~g}$ of load. The ARL OES 8860 Optical Emission Spectrometer and the Rigaku - ZSX Primus II X-Ray Spectrometer were utilized to perform chemical analyses of the cross-sectional samples in percentage weight extracted from the WAAM processed component.

\section{EXPERIMENTAL RESULTS}

Figure $4 \mathrm{a}$ and $4 \mathrm{~b}$ show the front view and X-ray results of the WAAM processed component, respectively. In addition, the macro section of the single bead wall of WAAM processed component which was composed of twenty layers is shown in Figure 4c. The results revealed that the defect free structure without any crack and porosity was obtained in both the additively manufactured layers and the interface.
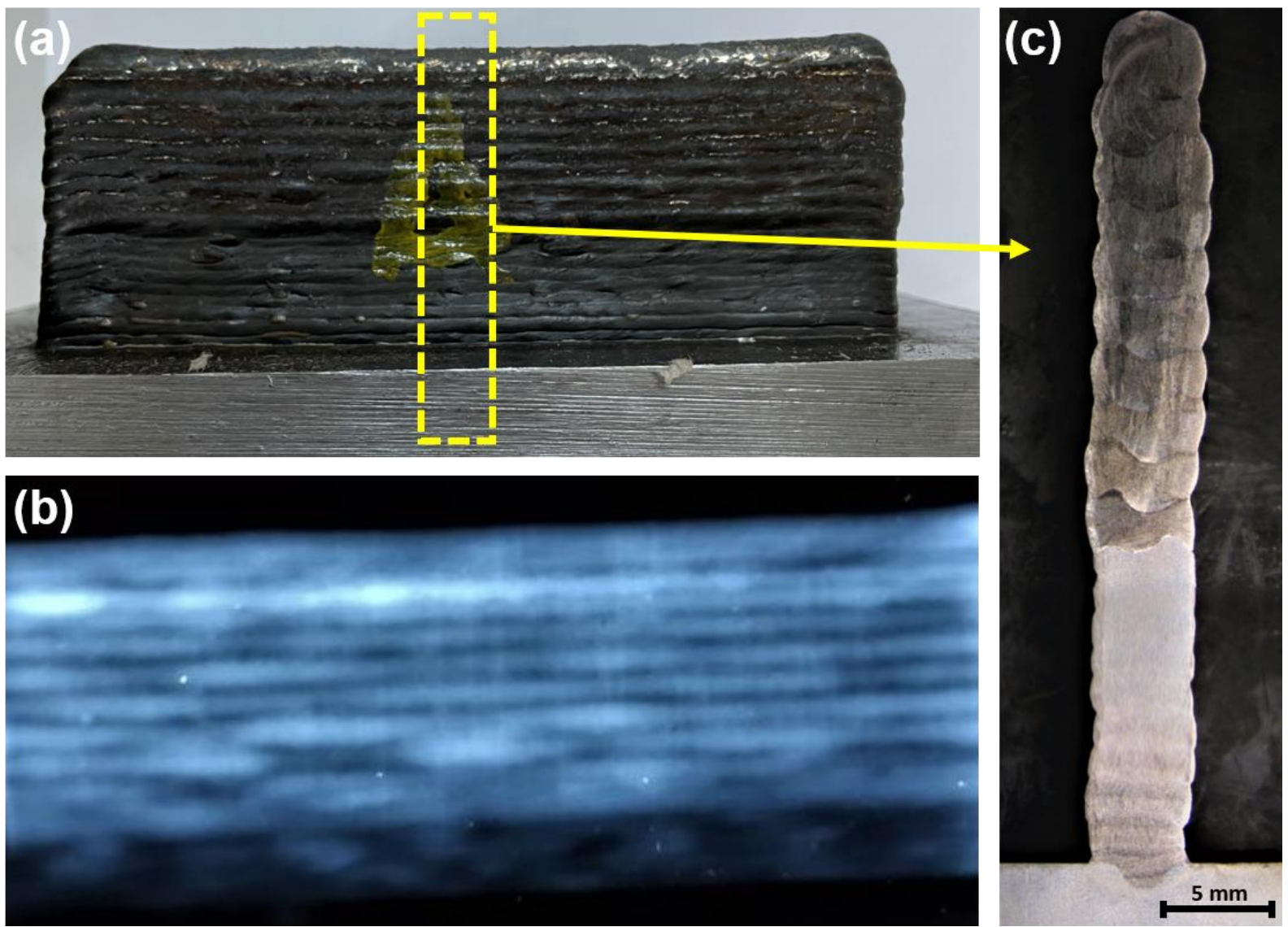

Figure 4. a) The front view, b) the X-ray result, and c) the macro-section of WAAM processed component. 
Figure 5 shows the overall microstructure of different locations of the component including the ER70 S-6 steel wall, transition zone and ER316L side, sectioned along the layer-building direction. The layers were composed of the typical polygonal ferrite (PF) as the primary phase and a low-volume fraction of acicular ferrite (AF) in the case of welding of ER70S-6 wire as shown in Figure 5a. It is well known that acicular ferrite develops at a slower cooling rate due to the continuous WAAM process [16]. The microstructure of ER 316L side shows dendritic columnar grains with certain amount of $\delta$-ferrite (darkcolored areas) in the austenite matrix (light-colored areas) that was aligned towards built direction as seen in Figure $5 \mathrm{~b}$. This is attributed to the directional solidification during the WAAM process. The ferrite to austenite transformation results in a skeletal and lathy ferrite formation. In addition, the transition zone indicates two distinct parts with a clear interface as shown in Figure 5c. It is observed a visible grain-growth orientation on the ER 70 S-6 side of the as-deposited specimen. This was caused by carbon poor (depleted) zone formation on heat-affected zone (HAZ) of ER 70 6-S side, consequently it led carbon-rich zone on stainless steel side. In other words, carbon migration from ferritic steel to weld metal occurs [17].
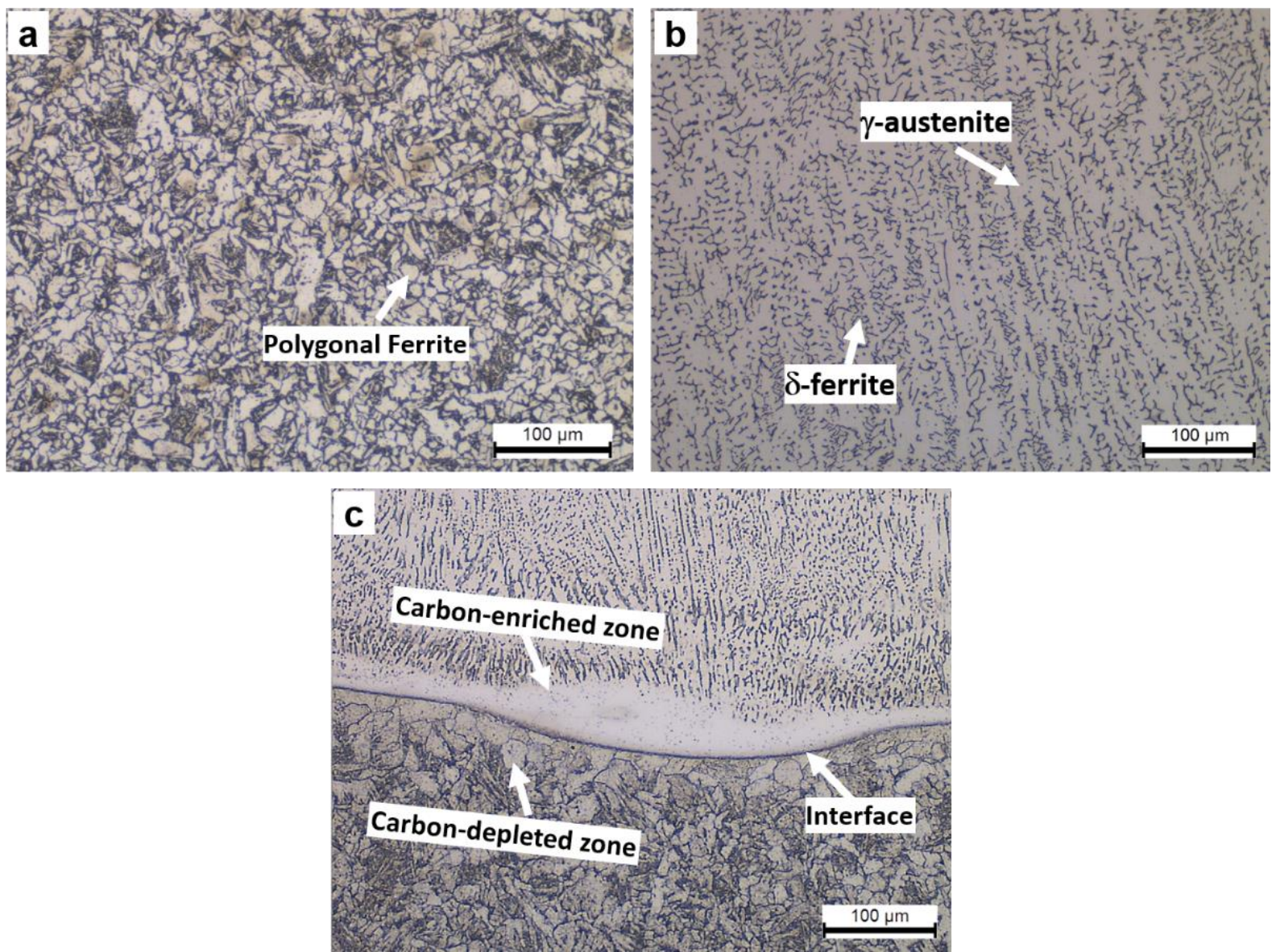

Figure 5. Micrographs of the deposited two layers with two different filler metals; a) ER 70 S-6 side, b) ER 316 L side, and c) interface.

The elemental chemical mapping images which are taken from the as-deposited specimen are shown in Figure 6. A decreased concentration of $\mathrm{Cr}, \mathrm{Ni}$ and $\mathrm{Mo}$ are observed at the interface of the as-deposited specimen. Additionally, the elemental migration of Fe is also visible from the ER 70 S-6 side of the specimen. 

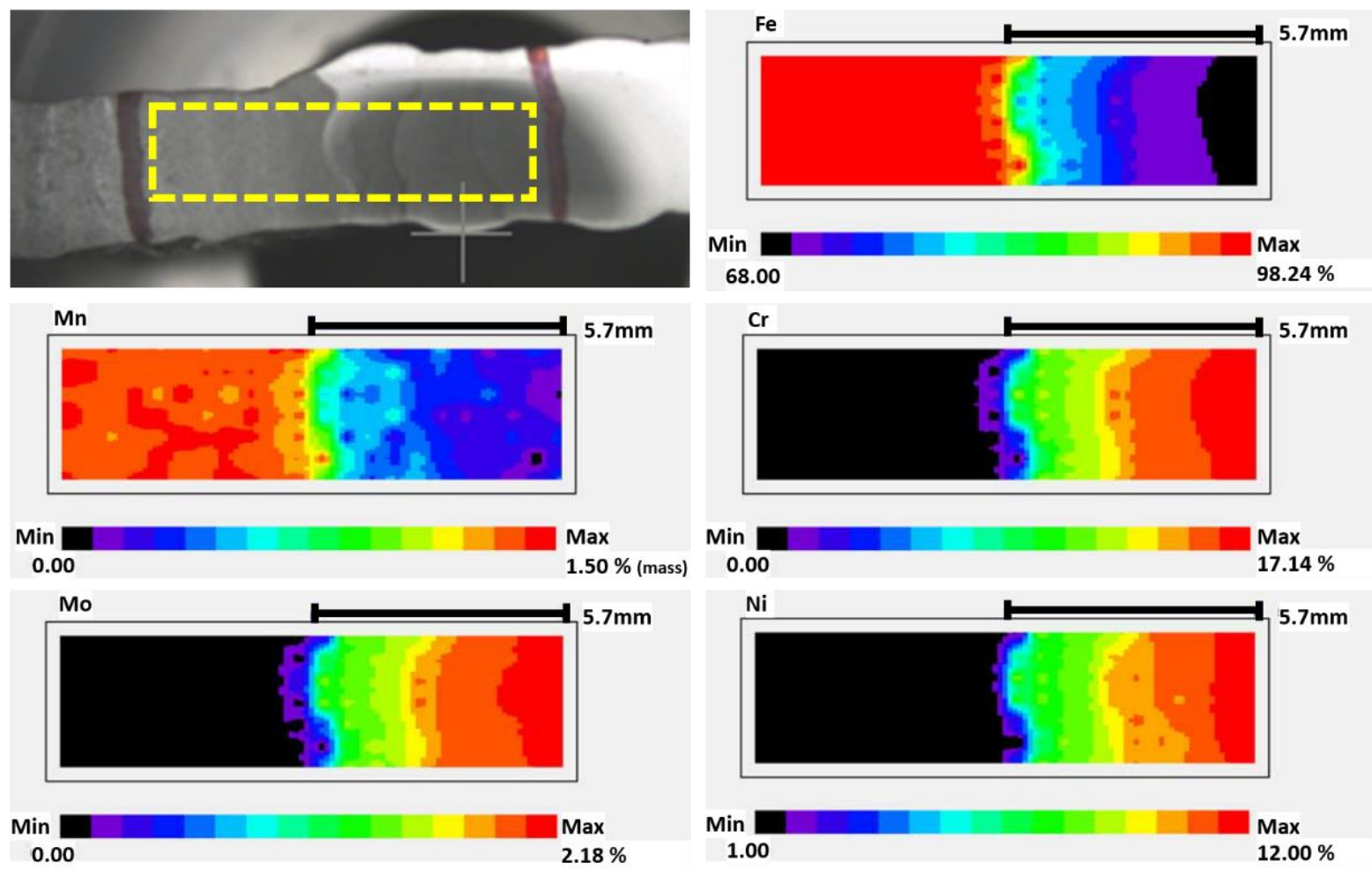

Min

Max

$2.18 \%$

1.00

$12.00 \%$

Figure 6. The elemental chemical composition mapping of the cross-sectional profiles of WAAM processed multilayer sample.

The microhardness profile of the as-deposited specimen is presented in Figure 7. The Vickers hardness test is conducted across the interface with the $35 \mathrm{~mm}$ of distance from each welding layer. The hardness value of HV5 is applied every $0.5 \mathrm{~mm}$ in the range of $70 \mathrm{~mm}$. The small changes in hardness values thought SS316L layers are due to the $\delta$-ferrite density in weld metal as mentioned in literature [17]. It is observed that the hardness value of the ER $316 \mathrm{~L}$ side is significantly higher than last layers of ER 70 6-S side.

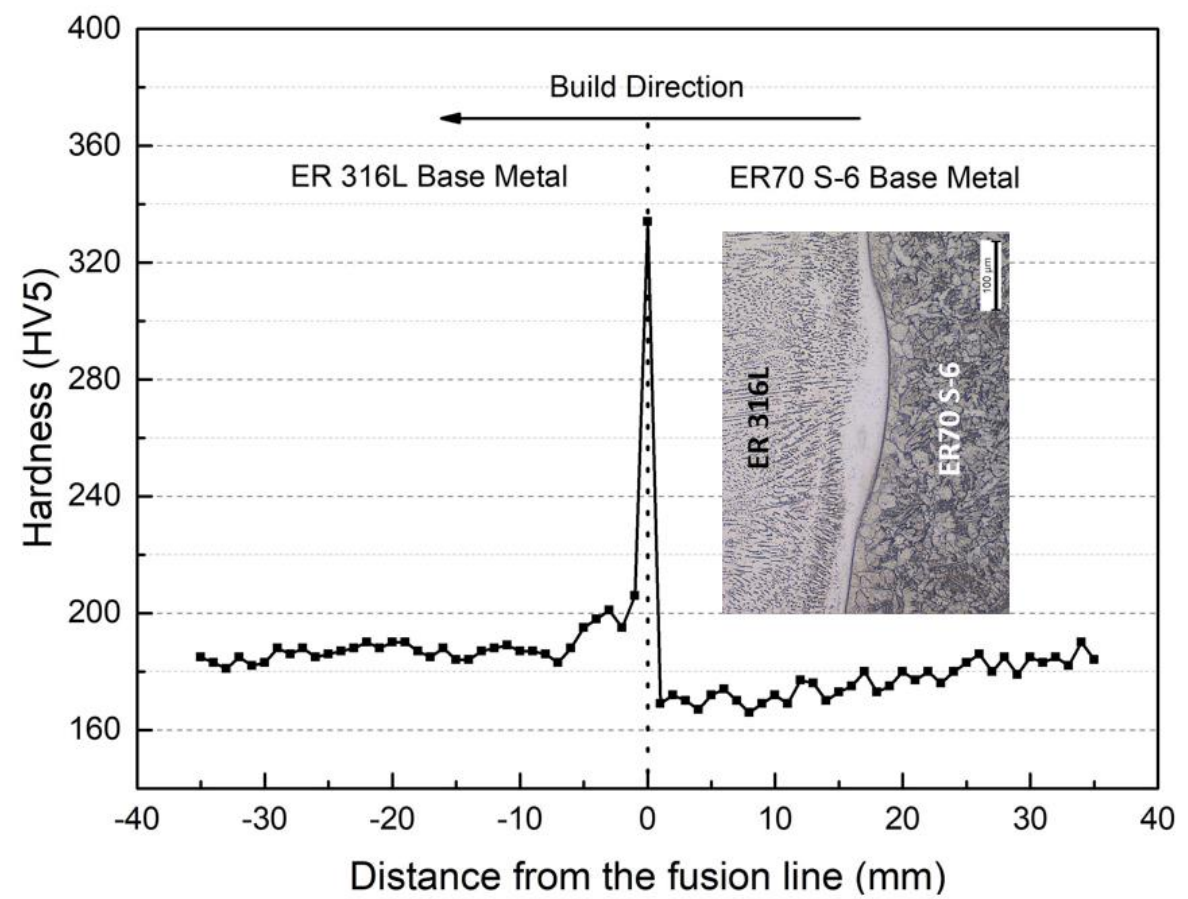

Figure 7. Vickers hardness test result of the as-deposited layers and interface. 
Moreover, the hardness values of ER 70 6-S side closer to interface dramatically decrease due to coarse grains and then tend to increase, as it gets closer to the substrate. This tendency can be attributed to the finer grains that occur due to the rapid cooling [18]. With the deposition of the ER 70 6-S wire layers, the cooling rate becomes almost steady. Thus, the hardness reaches about $12 \mathrm{~mm}$ away from the fusion boundary. In addition, the highest hardness value is recorded at the bimetallic interface because of thermal cycles occurring during WAAM process. This hardness increase can be attributed to the rapid cooling of the first ER 316L layer and the possibility of higher $\mathrm{C}$ and Fe concentration due to migration from ER 70 6-S side.

\section{CONCLUSION}

In this study, a bimetallic defect-free component is successfully manufactured via wire arc additive manufacturing technology using low carbon steel and austenitic stainless steel welding wires. The main process parameters which are welding current level, torch linear movement rate, wire feed rate, torch height, shielding gas, flow rate and tool path orientation are determined for the as-deposited layers of the ER 70 S-6 and ER 316L welding wires. The microstructure, hardness as well as the composition of the as-deposited specimen are analyzed for the ER 70 S-6 and ER 316L sides. The interface which is taken from two welding inter-pass with ER 70 S-6 and ER 316L is examined carefully. Any welding defects are observed from the interface. The highest hardness value is recorded at the bimetallic interface due to $\mathrm{Fe}$ and $\mathrm{C}$ migration through the interface layer. Moreover, a visible grain-growth orientation on the ER 70 S-6 side of the as-deposited specimen. A ferrite to austenite transformation is seen on the ER 316L side of the interface. In future works, the influence of the process parameters on the macro and microstructure will be studied.

\section{REFERENCES}

1. Frazier, W.E., "Metal additive manufacturing: A review", Journal of Material Engineering and Performance, Vol. 23, Pages 1917-1928, 2014.

2. Williams, S.W., Martina, F., Addison, A. C., Ding, J., Pardal, G., Colegrove, P., "Wire+Arc additive manufacturing", Materials Science and Technology, Vol. 32, Issue 7, Pages 641-647, 2016.

3. Leal, R., Barreiros, F.M., Alves, L., Romeiro, F., Vasco, J.C., Santos, M., Marto, C., “Additive manufacturing tooling for the automotive industry", The International Journal of Advanced Manufacturing Technology, Vol. 92, Pages 1671-1676, 2017.

4. Pan, Z., Ding, D., Wu, B., Cuiuri, D., Li, H., Norrish, J., “Arc welding processes for additive manufacturing: A review", Transactions on Intelligent Welding Manufacturing, Vol. 1, Pages 3-24 2018.

5. Mehnen, J., Ding, J., Lockett, H., Kazanas, P., "Design study for wire and arc additive manufacture", International Journal of Product Development, Vol. 19, Issue 2, Pages 2-20, 2014.

6. Jin, W., Zhang, C., Jin, S., Tian, Y., Wellmann, D., Liu, W., "Wire arc additive manufacturing of stainless steels: A review", Applied Sciences, Vol. 10, Issue 5:1563, 2020.

7. Chen, Z., Yufei, L., Ming, G., Xiaoyan, Z., "Wire arc additive manufacturing of Al-6Mg alloy using variable polarity cold metal transfer arc as power source", Materials Science \& Engineering A, Vol. 711, Pages 415423, 2018.

8. Shen, C., Pan, Z., Ma, Y. et al., "Fabrication of iron-rich Fe-Al intermetallics using the wire-arc additive manufacturing process", Additive Manufacturing, Vol. 7, Pages 20-26, 2015.

9. Colegrove, P., Coules, H., Fairman, J., Martina, F., Kashoob, T., Mamash, H., Cozzolino, L.D., "Microstructure and residual stress improvement in wire and arc additively manufactured parts through highpressure rolling", Journal of Materials Processing Technology, Vol. 213, Pages 1782-1791, 2013. 
10. Li Xiong, J., Li, Y. R., Yin, Z., "Influences of process parameters on surface roughness of multi-layer singlepass thin-walled parts in GMAW-based additive manufacturing" Journal of Materials Processing Technology, Vol. 252, Pages 128-136, 2018.

11. Wilson, I.L.W. Gourley, R.G., Walkosak, R.M., Bruck, G.J., "The effect of heat input on microstructure and cracking in alloy 625 weld overlays", Proceedings of the International Symposium on the Metallurgy and Applications of Superalloys 718, 625 and Various Derivatives, Pages 735-747, Pittsburgh, 1991.

12. Chaurasia, M., Sinha, M.K., "Investigations on process parameters of wire arc additive manufacturing (WAAM): A review”, Advances in Manufacturing and Industrial Engineering, Pages 845-85, 2021.

13. Ahsan, M.R.U., Tanvir, A.N.M., Ross, T., Elsawy, A., Oh, M.-S. and Kim, D.B., "Fabrication of bimetallic additively manufactured structure (BAMS) of low carbon steel and $316 \mathrm{~L}$ austenitic stainless steel with wire + arc additive manufacturing", Rapid Prototyping Journal, Vol. 26, Pages 519-530, 2020.

14. Kumar, S.M., Kannan, A.R., Kumar, N.P., Pramod, R., Shanmugam, N.S., Vishnu, A.S., Channabasavanna, S.G., "Microstructural features and mechanical integrity of wire arc additive manufactured SS321/Inconel 625 functionally gradient material", Journal of Materials Engineering and Performance, Vol. 30, Issue 8, Pages 5692-5703, 2021.

15. Xu, X., "Wire arc additive manufacturing of new and multiple materials", Ph.D. Thesis, Cranfield University, Cranfield, 2019.

16. Haselhuhn, A.S., Wijnen, B., Anzalone, G.C., Sanders P.G., Pearce J.M., "In situ formation of substrate release mechanisms for gas metal arc weld metal 3-D printing", Journal of Materials Processing Technology, Vol. 226, Pages 50-59, 2015.

17. Yılmaz, R., Tümer, M., "Microstructural studies and impact toughness of dissimilar weldments between AISI $316 \mathrm{~L}$ and AH36 steels by FCAW", The International Journal of Advanced Manufacturing Technology, Vol. 67, Pages 1433-1447, 2013.

18. Kapustka, N., Conrardy, C., Babu, S., Albright, C., "Effect of GMAW process and material conditions on DP 780 and TRIP 780 welds", Welding Journal, Vol. 87, Issue 6, Pages 135-148, 2008. 